Journal of Teacher Education for Sustainability, vol. 13, no. 2, pp. 59-69, 2011

\title{
REORIENTING LEADERSHIP STYLES FOR SUSTAINABLE EDUCATION
}

\author{
Christianah Oluwatoyin Oyetunji \\ Limkokwing University of Creative Technology, Botswana
}

\begin{abstract}
This paper describes the leadership style which can sustain education in Botswana community junior secondary schools (CJSS). The concept was examined based on the policy of education in Botswana, Botswana's vision for 2016 and the current situation in schools. Data was collected by means of a questionnaire and semi-structured interviews from a random sample of community junior secondary school teachers and head-teachers in Botswana. The data suggests that the head-teacher's leadership style affects teachers' and pupils' attitude towards a job and studies and that a participatory leadership style promotes sustainable education in schools. These findings can be useful for education policy makers, school administrators and researchers seeking to promote sustainable improvement in education.
\end{abstract}

Key words: leadership style, sustainable education, head-teacher-teacher relationship, school improvement, vision 2016

\section{Introduction}

The progress of a school reflects the head-teacher's leadership (Dubin, 2006) and a continuous improvement in a school is one of the tools for measuring the effectiveness of the head-teacher's leadership (Fullan, 2006). While there is evidence that head-teacher-teacher and teacher-teacher relations affect school improvement, the nature of these relationships has not been given due attention in the area of research (Barnett \& McMcormick, 2004). In some Botswana secondary schools, improvement in both teachers' and pupils' performance is more an ideal than a reality. Worse still, the situation in some schools is deteriorating as both the teachers and pupils are failing in their responsibilities.

For many decades, the system of education in Botswana was $7+3+2+4$; that is, 7 years of primary education (usually referred to as Basic Education), 3 years of junior secondary, 2 years of senior secondary and 4 years of university education. The mid 1980's saw a change in the education system; a $7+2+3+4$ structure was introduced to replace the existing system of $7+3+2+4$ as a transitional step to $6+3+3+4$. In essence, Basic Education was ex- 
panded from seven to nine years. Botswana views Basic Education as the foundation of lifelong learning and human development (Molosi, 1993). However, there were major disadvantages with this structure and with the envisaged $6+3+3+4$; for instance, the public was highly critical of the quality of Basic Education as many of the junior secondary school leavers were not absorbed in the labour market for lack of adequate communication, numeracy and life skills. Therefore, the $7+3+2+4$ system was reintroduced (Ministry of Education, 1993). In the 1990's, the government encouraged community participation in the running of junior secondary schools through the formation of local Board of Governors. The community, however, was not forthcoming in its support for the schools and in 2004 the Ministry of Education decided to take full control of all the community junior secondary schools (CJSS).

In Botswana secondary schools, the head-teacher is responsible for the supervision of staff and for efficient administration of the school. It is the duty of every teacher to exercise the functions of their post in accordance with the standard of professional conduct and to promote the education and welfare of students and the general efficiency of the school. A teacher is required to give the head-teacher their fullest support and loyalty at all times and to obey any lawful order given by the head-teacher or any other teacher to whom he/she has delegated his/her authority (Ministry of Education, 1976). In essence, the head-teacher is expected to work with teachers in a manner that enhances effectiveness in the school. Despite the importance of the relationship between the head-teacher and teachers within a school, only one study has been conducted on this relationship in Botswana. Beleme's (2005) study indicates that teachers believe sympathy and support characterise female headteachers' leadership styles while their male counterparts were perceived as domineering and forceful.

Botswana policy on education stresses the need for the school to mould and produce reliable and productive citizens (Ministry of Education, 1994). However, Phaswana (1996) and Mungoo (2003) observed that pupils are disinterested and disoriented. In addition, Nduchwa (1998) and Isaiah's (2006) findings suggest that some Botswana CJSS male teachers lack professional ethics as they have unhealthy relationships with pupils. Many secondary school teachers have a negative attitude towards their profession which has caused concern among parents and stakeholders who note absenteeism and negligence of duties among CJSS’ teachers (Isaiah, 2006).

Both pupils' and teachers' attitudes are causing a gradual decline in the performance of secondary school pupils (Phaswana, 1996). In addition, a lack of incentives from the government and unsatisfactory conditions of service such as low remuneration, unaddressed teachers' welfare issues and slim chances of progress are contributing to the low selfesteem of Botswana teachers (Isaiah, 2006).

Nevertheless, Botswana is working towards realising an ambitious set of goals by 2016. The country projects that by the year 2016, Botswana should achieve a better quality life, compete at international level in all areas and obtain adequate competent manpower in all fields. In other words, the country is working towards achieving a sustainable society and providing quality education is one of the main strategies to realise that goal (Presidential Task Group, 1997). Thus, a crucial question to consider is what can be done to improve the situation within schools so that Botswana can accomplish this dream in 2016? What 
factors are contributing to the teachers' negative attitude in schools? Could one major factor be the head-teachers' lack of effective leadership skill and styles? This research investigates the effect of leadership style on teachers' morale in relation to school improvement. An appropriate head-teacher leadership style may help improve teachers' attitudes and ability to focus on the core functions of schooling and contribute to the education sector's ability to lead the nation in its effort to achieve its goal by 2016 .

\section{Leadership style}

Various leadership approaches are found within the literature. The empirical research reported in this paper is based on the Hersey and Blanchard's situational approach to leadership which encompasses two key forms of leaders' behaviour: employeecentred/consideration and production-centred/initiating structure. This approach was initiated at the University of Michigan and Ohio State University in 1945 (Hersey \& Blanchard, 1988) and various studies sought to identify the behaviours that account for leaders' effectiveness. Findings show that employee-centred or highly-considerate leaders are sensitive to subordinates' feelings and strive to make things pleasant for them. In contrast, productioncentred or highly initiating structure leaders emphasise task completion (Schermerhorn, Hunt, \& Osborn, 2000).

Leadership style is the behaviour pattern the leader exhibits in the process of influencing the activities of followers as perceived by the followers (Hersey \& Blanchard, 1993). This approach stresses that there is no single effective style in all situations and that effective leadership depends on the ability of the leader to determine the readiness level of the subordinates before selecting the appropriate style (Hersey \& Blanchard, 1977). The approach is used to determine which one of four leadership styles (telling, selling, participating and delegating) suits the situation (readiness level of subordinates to perform and complete a specific task) to improve performance (Hersey, Blanchard, \& Johnson, 2001). Hersey \& Blanchard (1993) single out the readiness level of subordinates as the main situational factor over and above other factors which moderate leadership styles and effectiveness.

The telling style is characterised by high task and low relationship. It is effective when dealing with subordinates with low readiness level. The subordinates lack both job-related skills and motivation. The manager gives detailed instructions on the task to be performed, provides support and closely supervises subordinates' work. He/she makes decisions without the subordinates' input, thus communication is one sided (Dubrin, 1998). The style is not effective when the manager is seen as an individual who imposes methods on others or who is only concerned with output (Hersey \& Blanchard, 1993).

The selling style comprises both high task and high relationship behaviour. It is appropriate when leading subordinates who have low to moderate readiness level. The manager gives specific instructions, supervises subordinates' work and provides the necessary support. Two-way communication is encouraged. It is ineffective if subordinates do not believe that the manager is genuine in his/her relationship and perceive him/her to be initiating more jobs than are needed (Hersey \& Blanchard, 1993). 
The participating style is characterised by low task and high relationship behaviour. It is appropriate when leading followers with high-to-moderate readiness level. The manager demonstrates trust in the subordinates and focuses on facilitating goal accomplishment. He/she provides support and builds subordinates' self-esteem by giving them freedom to utilise their initiative while the manager acts as a facilitator in problem-solving and decision-making processes (Prerez, Milstein, Wood, \& Jacquez, 1999). It is ineffective when subordinates perceive the manager as an individual who is interested in peace and harmony at the expense of task accomplishment (Hersey \& Blanchard, 1993).

The characteristic of the delegating style is low task and low relationship behaviour. It is used effectively when leading subordinates with high readiness level. The subordinates are very competent and highly motivated. Therefore, the manager tells them what to do and provides little or no direction. Innovations are encouraged by the manager who demonstrates trust and confidence by supporting the subordinates. This style is ineffective when subordinates feel that the manager is providing little structure (Hersey \& Blanchard, 1993). In each case, the choice of leadership style depends on subordinates' readiness level and the use of the appropriate style is pivotal to subordinates' performance.

\section{The concept of sustainable education}

Sustainable education means education that is capable of continuing on at a certain level (Bodnar, 2007). The idea of sustainable education emerged because of the need to close the gap between the existing situation and the desired goal (Hearthstone, 2007). This author opines that the difference between the desired goal and the current reality should propel sustainable education and that the process of setting desired standards is the first step towards sustainable education.

\section{Methodology}

\section{Research questions}

This paper investigates the different leadership styles head-teachers use, their effect on teachers' efficiency and, hence, upon school improvement. The paper addresses three questions: What different leadership styles are used by head-teachers? What is the effect of head-teachers' leadership styles on teachers' commitment? How can the present situation in Botswana secondary schools be improved?

\section{Participants}

35 schools from the 206 CJSS, spanning both rural and urban areas in Botswana, was selected using stratified technique. Based on Teaching Service Management statistics, 168 schools are in rural areas while 38 schools are in urban areas, which correspond to 82 percent and 18 percent respectively of the total number of schools (206 schools). 29 schools 
(82 percent of 35) in rural and six schools (18 percent of 35) in urban areas were randomly selected. There are 6621 teachers in rural areas and 1727 teachers in urban areas: 79 percent and 21 percent respectively of the whole population of 8348 teachers in community junior secondary schools in Botswana. 474 teachers (79 percent of 600) and 126 teachers (21 percent of 600) in rural and urban areas respectively were randomly selected making a total of 600 teachers. A total of 20 head-teachers in both rural and urban areas also participated in the study.

\section{Research instrument}

Data was collected through the use of the Leadership Effectiveness Adaptability Description (LEAD-Other) questionnaire which was adapted for the purpose of this study. The LEAD instruments are specifically designed to measure leadership behaviour and have been proven effective for measuring the leadership style of managers (Hersey \& Blanchard 1993). Hersey \& Blanchard (1977) assert that the LEAD-Other instrument is appropriate for measuring leadership style because it is based on the followers' perceptions of the leader's behaviour. The LEAD-Self measures the leaders' perception of their behaviour rather than their style. Thus, the LEAD-Other instrument was used. However, it would be useful to compare leaders' and followers' perceptions of the leader's style so as to identify the dissimilarity between self-perception and others' perception (Hersey \& Blanchard, 1988). To capture this discrepancy, a semi-structured interview guide was used to gather information from 20 randomly selected head-teachers regarding how they perceived their leadership styles. The interview guide questions were coined from the LEAD-Self questionnaire.

The LEAD-Other instrument consists of 12 situations which are divided into four groups. Each group describes a different readiness level of followers. The following are examples of situations from each of the groups: (a) The staff are not responding lately to this leader's friendly conversation and obvious concern for their welfare. Their performance is declining rapidly (Low readiness level), (b) the observable performance of the staff is increasing. The leader has been making sure that all members are aware of their responsibilities and expected standards of performance (Low-to-moderate readiness), (c) The staff is struggling to solve a problem. The leader has normally left them alone. Staff performance and interpersonal relations have been good (Moderate-to-high readiness) and (d) The leader is considering a change. The staff has a fine record of accomplishment. They respect the need for change (high readiness level). Four alternative actions were provided for each situation and arranged in order of their effectiveness for each situation.

\section{Results}

Table 1 provides the information about the leadership styles of all the participating schools. 
Table 1. A summary of the LEAD-Other responses

\begin{tabular}{|c|c|c|c|c|}
\hline School & Telling & Selling & Participating & Delegating \\
\hline 1 & 42 & 57 & 27 & 6 \\
\hline 2 & 25 & 53 & 36 & 18 \\
\hline 3 & 59 & 78 & 69 & 22 \\
\hline 4 & 20 & 57 & 43 & 0 \\
\hline 5 & 51 & 107 & 63 & 7 \\
\hline 6 & 46 & 64 & 63 & 7 \\
\hline 7 & 64 & 97 & 57 & 46 \\
\hline 8 & 75 & 88 & 40 & 13 \\
\hline 9 & 27 & 18 & 19 & 32 \\
\hline 10 & 56 & 122 & 115 & 7 \\
\hline 11 & 18 & 24 & 34 & 8 \\
\hline 12 & 62 & 66 & 85 & 63 \\
\hline 13 & 27 & 19 & 26 & 12 \\
\hline 14 & 48 & 79 & 60 & 5 \\
\hline 15 & 19 & 67 & 59 & 23 \\
\hline 16 & 21 & 74 & 65 & 8 \\
\hline 17 & 37 & 72 & 30 & 5 \\
\hline 18 & 29 & 21 & 41 & 29 \\
\hline 19 & 54 & 92 & 57 & 37 \\
\hline 20 & 33 & 35 & 58 & 18 \\
\hline 21 & 27 & 69 & 74 & 10 \\
\hline 22 & 46 & 48 & 52 & 22 \\
\hline 23 & 48 & 85 & 51 & 8 \\
\hline 24 & 26 & 62 & 55 & 13 \\
\hline 25 & 62 & 70 & 31 & 5 \\
\hline 26 & 66 & 87 & 47 & 16 \\
\hline 27 & 21 & 41 & 61 & 21 \\
\hline 28 & 35 & 77 & 67 & 25 \\
\hline 29 & 49 & 83 & 54 & 18 \\
\hline 30 & 16 & 30 & 36 & 14 \\
\hline 31 & 29 & 21 & 41 & 29 \\
\hline 32 & 21 & 49 & 46 & 4 \\
\hline 33 & 101 & 86 & 30 & 23 \\
\hline 34 & 20 & 81 & 67 & 0 \\
\hline 35 & 70 & 89 & 58 & 23 \\
\hline Total & 1450 & 2268 & 1817 & 597 \\
\hline Total (\%) & 23.65 & 36.97 & 29.63 & 9.74 \\
\hline
\end{tabular}

The highest scores of $65.7 \%$ of the head-teachers are located in a quadrant two which represents a high relationship and high task leadership behaviour. This implies that the majority of the head-teachers that participated in the study used the selling style in their relationship with teachers.

The highest scores of nine schools (25.7\%) are situated in quadrant three which is characterised by high relationship and low task orientation. These head-teachers used the participative leadership style. The highest scores of two schools are found in quadrant one which represents a high task and low relationship orientation. Thus, the dominant style of $5.7 \%$ of the head-teachers under study was telling. The highest score of one school falls in 
quadrant four which represents a low relationship and low task orientation. That is, $2.8 \%$ of the head-teachers used the delegating style of leadership in running their schools.

\section{Interview data}

The majority of the head-teachers reported that they completely depend on the support of other members of staff for the successful implementation of any change and running of school in general. Therefore, they consult and encourage active participation of other members. This suggests that consultative and participative styles of leadership are exercised by most head-teachers when dealing with issues that concern the school.

The comparison of head-teachers behaviour, as perceived by their teachers in Table 1, and how the head-teachers thought they behaved as gathered from their responses to the interview questions, indicate that there is a difference between the teachers' views and the head-teachers' opinions: what the teachers said did not correspond with the head-teachers perceptions about their style of leadership. Based on the perceptions of teachers, the majority $(65.7 \%$ in LEAD-Other) of the head-teachers used the selling style whereas the headteachers claimed to use the consultative or participative.

\section{Discussion}

As indicated above, $65.7 \%$ of the head-teachers used the selling leadership style. This style stresses a high task and high relationship orientation which suggests that head-teachers may assume that teachers have not yet reached a readiness level at which less emphasis can be placed on task. The need for high emphasis on relationships suggests that the head-teachers are not satisfied with staff members who will just perform tasks but are probably interested in having staff members who are mature, conscientious, approachable and devoted, teachers who take pleasure in their job (Hoy \& Sabo, 1998). As a result, the head-teachers look for opportunities to reinforce appropriate behaviour and encourage a two-way communication (Hersey \& Blanchard, 1993). This selling style should have an impact on the atmosphere that prevails at these schools. The teachers who realise that their head-teachers are not only concerned about the accomplishment of tasks but are equally concerned about their personal welfare would, most likely, endeavour to satisfy their head-teachers by willingly working hard to meet their head-teachers' expectations. This supposes, however, that everybody stands to gain from this kind of relationship.

Nine (25.7\%) of the head-teachers used the participating style of leadership. This style is high relationship and low task oriented because head-teachers may assume that the teachers are at or above average level of readiness, that they are capable even though they are not performing. The assumption is that they lack motivation that can bring them to the level of effectiveness of which they are capable. One of the things that could contribute to the teachers' lack of motivation is a situation where head-teachers attempt to influence teachers to like them at the expense of the work to be done. If teachers work according to the level of their readiness, the anticipated atmosphere will be one of trust in which teachers express a willingness to do the work for which they are equipped. On the other hand, if the head- 
teachers try to buy teachers' affection at the expense of task accomplishment, the atmosphere is likely to be friendly, but the work will suffer (Hersey \& Blanchard, 1993).

Only one (2.8\%) of the head-teachers used the delegating style of leadership. The atmosphere in this school should be characterised by trust, self-esteem and personal worthiness. However, if the head-teacher delegates when the teachers are at low level of readiness, which Hersey \& Blanchard (1977) describe as abdication where the head-teachers abandon their responsibilities, the expected atmosphere will be one of lawlessness and unproductivity. For instance, if the task of organising a sport day is given to a group of teachers which neither has relevant experience nor interest in sports, positive results are likely only if the head-teacher provides direction, support and supervises closely. Otherwise, the teachers may be confused, may do what they like with their time and in the midst of the confusion, some of them may become frustrated, lazy or apathetic.

Two (5.7\%) of the head-teachers used the telling style of leadership. This indicates that the teachers are no more performing at their readiness level, and, therefore, their performance is declining. The use of telling style of leadership with the set of teachers in this study may lead to a decline in teachers' performance. This is because the teachers have the required skills and knowledge to perform effectively. The teachers were probably not performing because the head-teachers were telling them what they already knew. If the teachers were given the opportunity to use their acquired skills and given necessary support by their head-teachers, the unproductive atmosphere would be likely to change for the better. For instance, most professionally trained teachers may not enjoy listening to detailed teaching procedures in a staff development workshop; some teachers may see it as a waste of their precious time, some may think that the head-teacher does not have confidence in them and some may think the head-teacher is too rigid wanting things done according to his/her specifications. All these perceptions may affect the teachers' attitudes towards their job. On the one hand, if trained teachers are given free hand to use their knowledge, skills and initiatives to manage teaching in their classrooms while the head-teacher provides tips and facilities to facilitate their work, their performance should be enhanced.

In addition, the discrepancy in the head-teachers' and teachers' perceptions of the behaviours of head-teachers may have contributed to teachers' low morale, lack of motivation and commitment and the prevailing situation in many schools. The teachers' lack of response to what the head-teachers believed to be a participative/consultative style underscores the notion that leadership style is determined by the followers' perceptions of their leader's behaviour. In attempting to identify leadership styles, how the head-teachers perceive their behaviour is unimportant because leadership style refers not to how leaders think they behave but to how their followers perceive that behaviour. How teachers perceive their head-teachers matters because it is those perceptions which determine how they respond to their head-teachers' leadership behaviours.

According to the findings of the paper, the majority of the head-teachers used the selling style of leadership. The Teaching Service Management statistics show that more than $95 \%$ of teachers in community junior secondary schools are well qualified. It follows that the selling style of leadership used by most head-teachers may not be suitable since the teachers studied most likely possessed the necessary skills to function effectively at that level. Most trained teachers are expected to have necessary job-related skills, although 
some may have the skills but not use them effectively. For the selling style to be effective, the readiness level of the followers should be low to moderate. That is, they should lack of necessary skills but be willing (Hersey \& Blanchard, 1993).

As mentioned above, many of the head-teachers used the selling style of leadership and a substantial number used this style inappropriately. Because the teachers who participated in this research were trained to be professional and work in collaboration with their head-teachers, the participating rather than the selling style of leadership may be more appropriate in dealing with them. To this end, the unprofessional behaviour of teachers in most of the schools could be linked to the inappropriate use of the selling style of leadership by many head-teachers.

Improvement in the relevance and quality of education is at the core of Botswana vision 2016. Therefore, the head-teachers in Botswana CJSS have a significant role to play in order for the country to realise this vision; they need to adopt the leadership style that will help both teachers and pupils improve their behaviour and performance and sustain that improvement. When the head-teacher involves teachers, pupils and other stakeholders in the running of the school, it should bring about improvement. When teachers realise that their contributions are sought and valued, it will boost up their self-esteem, give them a sense of belonging and cause them to live up to their responsibilities as professional teachers and increase their commitment to their jobs and pupils.

Teachers' commitment will most likely influence pupils' attitude towards school and their studies. They are likely to work hard to meet their teachers' expectations. As the country strives to become a sustainable society come 2016, constant improvement of teachers and pupils' behaviour and performance in school indicates a movement towards sustainable education, a path the country of Botswana needs to follow to reach her destination. The situation in schools reflects the effectiveness of the head-teacher's leadership style which is crucial to achieving the country's desired goals, not only in the education sector but in other sectors of the government.

\section{Suggestions}

In the light of these findings the Ministry of Education should organise extensive in-service development programmes and/or encourage the head-teachers to go for short courses in educational management with specific emphasis on leadership skills and appropriate use of styles so that schools are run in a manner that will motivate teachers to be more productive and pupils to be more achievement oriented. Because education is the pillar of the Vision 2016, teachers' efficiency cannot be compromised if that vision is to be realised. Therefore, it is imperative for the government to attend to some of the teachers' requests to encourage them to take their rightful positions in the nation's journey to a better Botswana in 2016.

Head-teachers should embrace a participative, collaborative style and involve teachers in the decision-making and execution of plans; teachers should handle their job concerns with maturity, use proper channels and exercise patience while waiting for the government to address issues. Teachers must share in the nation's vision and their full participation in 
planning and accomplishing the plans towards Vision 2016 is critical. Thus, teachers are encouraged to be committed, faithful and to see to the success of the pupils they teach.

\section{Conclusion}

The head-teachers of the schools studied used different styles of leadership namely: telling, selling, participating and delegating. The majority of the head-teachers (66\%) used the selling style of leadership in their relationship with teachers, but they seemed to use it inappropriately as their teachers did not respond positively to this style. The selling style of leadership is characterised by directive head-teacher behaviour which does not appear to be suitable for professional teachers; the calibre of the teachers who participated in this study. Thus, the inappropriate use of the selling style of leadership is a major factor contributing to teachers' unenthusiastic behaviour. The need for the head-teachers to interact with teachers appropriately cannot be overemphasised. The head-teachers need to adopt the participating leadership style which promotes inclusion of teachers in decision-making, teachers' development, collaboration and power sharing, thus enhancing collegiality and positive attitude to school and work. They need to provide the kind of leadership that will spur teachers to work with enthusiasm, rekindle pupils' interest in schooling so that they focus on achieving their educational goals and increase the possibility of realising the country's vision for the year 2016. Now is the time for all stakeholders to embrace and actively practise sustainability in the education system so that the new picture of Botswana can come to be as envisaged.

\section{References:}

Barnett, K., \& McCormick, J. (2004). Leadership and individual principal-teacher relationships in schools. Educational Administration Quarterly, 40(3), 406-434. DOI: 10.1177/0013161X03261742.

Beleme, O. (2005). Teachers' perceptions about the performance of a female head of school: A case of Molepolole community junior secondary schools. Unpublished Master's dissertation, University of Botswana, Gaborone, Botswana.

Bodnar, E. (2007). Sustainable education. Retrieved from http://www.blog.ethanbodnar.co $\mathrm{m} / 2007 / 06 / 22 /$ sustainable-education

Dubin, A. E. (2006). Conversations with principals: Issues values and politics. London, UK: Sage Publications.

Dubrin, A. J. (1998). Leadership: Research, findings, practice and skills (2nd ed.). Boston, USA: Houghton Mifflin Company.

Fullan, M. (2006). Turnaround leadership. San Francisco, USA: Jossey-Bass.

Hearthstone, J. (2007). Ecologically and socially sustainable education: Creating a sustainable world. Retrieved from http:/www.modelearth.org/ecosocsused.html

Hersey, P., \& Blanchard, K. H. (1977). Management of organizational behaviour: Utilizing human resources (3rd ed.). New Jersey, USA: Prentice Hall. 
Hersey, P., \& Blanchard, K. H. (1988). Management of organisational behaviour: Utilizing: Human resources (5th ed.). New Jersey, USA: Prentice Hall.

Hersey, P., \& Blanchard, K. H. (1993). Management of organizational behavior: Utilizing human resources (6th ed.). New Jersey, USA: Prentice Hall.

Hersey, P., Blanchard, K. H., \& Johnson, D. E. (2001). Management of organizational behavior: Leading human resources (8th ed.). New Jersey, USA: Prentice-Hall.

Hoy, W. K., \& Sabo, D. J. (1998). Quality middle school: Open and healthy. California, USA: Corwin Press Inc.

Isaiah, M. N. (2006). Factors influencing teachers' job satisfaction in CJSS in south central region of Botswana. Unpublished doctoral dissertation, University of Botswana, Gaborone, Botswana.

Ministry of Education. (1976). Code of regulations governing the conditions of service of teachers. Gaborone: Botswana Government Printer.

Ministry of Education. (1993). Report of the National Commission on Education. Gaborone: Botswana Government Printer.

Ministry of Education. (1994). Revised national policy on education. Gaborone: Botswana Government Printer.

Molosi, P. O. (1993). Current government policy on education and analysis of the implementation of the White Paper No 1 of 1977. In S. Seisa \& F. Youngman (Eds.), Education for all in Botswana (pp. 41-54). Gaborone: Botswana Government Printer.

Mungoo, J. K. (2003). Nature and causes of student indiscipline in secondary schools. Unpublished Master's dissertation, University of Botswana, Gaborone, Botswana.

Nduchwa, B. (1998). Problems of teenage pregnancy in community junior secondary schools: A case study of Ipeleng CJSS. Unpublished Master's dissertation, University of Botswana, Gaborone, Botswana.

Phaswana, K. (1996). School effectiveness. In R. Charakupa, J. Odiharo \& M. Rathedi (Eds.), Botswana's challenge for quality education into the 21st century (pp. 135141). Gaborone: Botswana Ministry of Education.

Prerez, A. V., Milstein, M. M., Wood, C. J., \& Jacquez, D. (1999). How to turn a school around: What principals can do. California, USA: Corwin Press Inc. Press.

Presidential Task Group. (1997). Vision 2016: Towards prosperity for all. Gaborone: Botswana Government Printer.

Schermerhorn, J. R., Hunt, J. G., \& Osborn, R. N. (2000). Organisational behaviour (7th ed.). New York, USA: John Wiley \& Sons.

\section{Correspondence:}

Dr Christianah Oluwatoyin Oyetunji, Faculty of Communication, Media and Broadcasting, Limkokwing University of Creative Technology, P.O. Box 70277, UB Post Office, Gaborone, Botswana. Email: ctoyetunji@yahoo.co.uk 